\title{
PAUL RIVET
}

l Instituto Colombiano de Antropología consagra este número de su revista a la memoria del insigne americanista, recientemente fallecido en Paris, Profesor Paul Rivet.

Fue Rivet el fundador del Instituto Etnológico $\mathrm{Na}$ cional, hoy Instituto Colombiano de Antropología. Su iniciativa, que fue secundada con entusiasmo y patriotismo por el entonces Presidente de la República, doctor Eduardo Santos, y por otros ilustres colombianos, se tradujo bien pronto en una realidad, a la cual dedicó el sabio francés toda su vocación científica $y$ de - maestro para empeñarse en la formación de una moderna escuela antropológica en nuestro pais.

Al rendir este homenaje póstumo a la memoria del fundador del Instituto consagramos también nuestra admiración y reconocimiento a la ciencia de Francia, que en forma pródiga ha secundado y sigue estimulando el desarrollo de las manifestaciones culturales de América Hispana. 


\section{RESOLUCION NUMERO 0002 DE 1958}

(abril 10)

por la cual se rinde homenaje a la memoria del Profesor Paul Rivet.

El Director del Instituto Colombiano de Antropología,

\section{CONSIDERANDO:}

Que el día 21 de marzo del presente año falleció en París el destacado americanista francés, Profesor Paul Rivet, ex-Director del Museo del Hombre y uno de los más preclaros exponentes de la ciencia antropológica de los últimos años;

Que durante más de diez lustros el Profesor Rivet estuvo dedicado por entero al estudio de los más remotos orígenes del hombre americano y a la valoración científica de los elementos más significativos de las culturas aborígenes del Nuevo Mundo;

Que además de su ponderosa tarea científica, el Profesor Rivet puso todo su entusiasmo de maestro de juventudes en la formación de profesionales de la antropología en distintos países de América;

Que durante su permanencia en Colombia, el Profesor Rivet fundó el Instituto Etnológico Nacional (hoy Instituto Colombiano de Antropología), en donde enseñó con celo y profundidad distintos aspectos de la Ciencia del Hombre hasta crear una escuela especializada que hoy rinde sus frutos en la investigación de las realidades antropológicas del país;

Que hasta los postreros momentos de su vida, el Profesor Rivet fue un amigo entrañable de Colombia y un convencido de sus grandes posibilidades en los altos menesteres de la cultura,

\section{RESUELVE:}

Exaltar la memoria del Profesor Rivet como el más sabio y decidido propulsor y orientador de los estudios antropológicos en Latinoamérica y en Colombia. 
Colocar en la Sala de Honor del Instituto Colombiano de Antropología el retrato de su ilustre fundador.

Celebrar un acto académico dedicado a honrar la memoria del desaparecido científico francés y a presentar al público los invaluables méritos de su tarea investigativa en el campo de los estudios americanistas.

Gestionar la adquisicón, por parte del Instituto Colombiano de Antropología, de los trabajos inéditos que sobre Colombia dejó el Profesor Rivet, para ser publicados en la Revista de la institución.

Manifestar a la Dirección del Museo del Hombre, a la Sociedad de Americanistas de Francia, a la señora Mercedes viuda de Rivet y a los demás familiares del extinto, el sentimiento de pesar del Instituto Colombiano de Antropología por el deceso del Profesor Rivet, cuya muerte constituye una pérdida irreparable para la ciencia de Francia y para la antropología americana.

Comuníquese y publíquese.

Dada en Bogotá, D. E., a los 10 días del mes de abril del año de 1958.

El Director del Instituto Colombiano de Antropología,

Luis Duque Gómez

El Secretario,

Francisco Márquez Yáñez 